\title{
EDUKASI GIZI SEIMBANG ANAK USIA 0-2 TAHUN PADA IBU-IBU DI KELURAHAN HARAPAN MULIA, KEMAYORAN/ JAKARTA PUSAT
}

\author{
Sri Wuryanti ${ }^{1)}$, Himmi Marsiati ${ }^{1)}$, Sri Hastuti Andayani ${ }^{1}$ \\ 1) Fakultas Kedokteran, Universitas Yarsi, Jakarta \\ E-mail: sriwuryanti@yarsi.ac.id \\ E-mail: himmi.marsiati@yarsi.ac.id \\ E-mail: sri.hastuti@yarsi.ac.id
}

\begin{abstract}
Abstrak
Data Riskesdas 2010 menunjukkan 5\% dari balita di Indonesia masih mengalami kekurangan gizi dan 37\% balita Indonesia mengalami gangguan pertumbuhan dan perkembangan otak. Salah satu penyebab dari permasalahan ini adalah kurangnya pengetahuan ibu tentang gizi balita. Untuk mencegah terjadinya malnutrisi pada balita, termasuk bayi usia dibawah 1 tahun, WHO merekomendasikan strategi global pemberian makan bayi dan anak, yaitu pemberian ASI eksklusif hingga usia 6 bulan dan mulai memberikan makanan pendamping ASI (MPASI) sejak usia 6 bulan dengan tetap melanjutkan pemberian ASI paling tidak sampai usia 2 tahun. Kelurahan Harapan Mulia terdiri dari 9 RW dan 12 RT. Di wilayah ini terdapat 10 Posyandu dengan jumlah balita sebanyak 1503 anak. Berdasarkan hasil data kegiatan Pengabdian kepada Masyarakat (PkM) pada bulan Desember 2016 di Kelurahan Harapan Mulia didapatkan pengetahuan dan pemahaman Ibu-ibu Kader tentang gizi di periode 1000 hari pertama kehidupan (1000 HPK) masih kurang, serta jumlah kader yang terlatih hanya 42\%. Melalui kegiatan pengabdian masyarakat yang berkelanjutan ini dengan sasaran wanita usia subur (WUS), ibu hamil atau ibu yang mempunyai baduta atau balita dan kader didapatkan peningkatan pengetahuan dan pemahaman tentang gizi seimbang untuk anak balita, khususnya anak usia 0-2 tahun.
\end{abstract}

\section{Kata Kunci: Gizi Seimbang Anak, Baduta/ Balita, Periode 1000 HPK}

\section{PENDAHULUAN}

Indonesia mengalami 2 masalah gizi yang besar. Selain masih kekurangan gizi, kita juga mulai kelebihan gizi. Kekurangan dan kelebihan gizi sama-sama berdampak negatif. Kekurangan gizi berhubungan erat dengan lambatnya pertumbuhan tubuh (terutama pada anak), daya tahan tubuh yang rendah, kurangnya kecerdasan dan produktivitas yang rendah. Adapun kelebihan gizi berisiko terkena berbagai penyakit kronis/degenerative, seperti hipertensi, diabetes mellitus, stroke, penyakit jantung, gout dan beberapa jenis kanker.

Data Riskesdas 2010 menunjukkan 5\% dari balita di Indonesia masih mengalami kekurangan gizi dan $37 \%$ balita Indonesia mengalami gangguan pertumbuhan dan perkembangan otak. Salah satu penyebab dari permasalahan ini adalah kurangnya pengetahuan ibu akan gizi balita.

Kekurangan gizi berhubungan erat dengan lambatnya pertumbuhan tubuh (terutama pada anak), daya tahan tubuh yang rendah, kurangnya kecerdasan dan produktivitas yang rendah. Masalah kekurangan gizi pada anak balita berhubungan erat keadaan gizi ibu waktu remaja dan saat hamil, oleh karena itu pencegahan masalah gizi tidak lagi difokuskan pada anak balita seperti selama ini, tetapi lebih difokuskan pada remaja perempuan, ibu hamil dan bayi sampai berumur dua tahun. 
Kelurahan Harapan Mulia mempunyai luas 53,45 Ha terdiri dari 9 RW dan 12 RT yang dihuni oleh $8.448 \mathrm{KK}$ dengan jumlah 27.086 jiwa. Kondisi Kelurahan Harapan Mulia adalah wilayah kumuh dan berpenduduk padat, dimana penduduknya terdiri dari berbagai suku bangsa, agama dan tingkat pendidikan Kelurahan Harapan Mulia tidak mempunyai mata pencaharian yang tetap, sebagian kecil karyawan kantor, PNS, dagang dan buruh. Di wilayah ini terdapat 10 Posyandu dengan jumlah balita sebanyak 1503 anak dan mempunyai kader sebanyak 86 orang, yaitu 36 kader terlatih dan 50 kader tidak terlatih. Berdasarkan data saat kegiatan pengabdian masyarakat pada bulan Desember 2016 di Kelurahan Harapan Mulia didapatkan pengetahuan dan pemahaman tentang gizi di periode 1000 hari pertama kehidupan (1000 HPK) sangat terbatas/kurang.

Kegiatan pengabdian masyarakat ini bertujuan meningkatkan pengetahuan, pemahaman dan kesadaran ibu-ibu kader, WUS, ibu hamil atau ibu yang mempunyai baduta atau balita tentang pentingnya kecukupan gizi anak usia 0-2 tahun atau periode 1000 HPK. Selain itu, membantu pemerintah dalam upaya percepatan perbaikan gizi melalui Gerakan Nasional Percepatan Perbaikan Gizi masyarakat dengan prioritas/fokus pada $1000 \mathrm{HPK}$.

\section{METODE PELAKSANAAN}

Metode yang dilakukan pada kegiatan ini adalah dengan cara edukasi melalui penyuluhan tentang gizi seimbang anak usia 0 sampai 2 tahun pada kader, wanita usia subur (WUS), ibu hamil atau ibu yang mempunyai baduta atau balita, serta pemberian buku saku berjudul "Sehat \& Cerdas Berkat Gizi Seimbang" pada setiap peserta. Buku ini berisi informasi tentang ASI, MPASI dan cara memonitor pertumbuhan dan perkembangan anak.

Kegiatan ini dilaksanakan di Ruang Publik Terpadu Ramah Anak (RPTRA) Kelurahan Harapan Mulia, Kemayoran/Jakarta Utara pada hari
Sabtu/16 Desember 2017. Acara diawali dengan pre test menilai pengetahuan para peserta dan diakhiri dengan post test untuk menilai peningkatan pengetahuan atau capaian dan keberhasilan kegiatan PkM.

\section{HASIL DAN PEMBAHASAN}

Kegiatan dihadiri oleh 42 peserta (84\% dari sasaran). Sebelum diberikan materi penyuluhan, dilakukan pre-test (lama 15 menit) untuk mengetahui tingkat pengetahuan ibu-ibu tentang gizi dan tumbuh kembang anak. Materi penyuluhan diberikan oleh 2 narasumber, yaitu dokter spesialis gizi dan dokter spesialis anak. Topik pertama berisi tentang gizi seimbang untuk anak 0-2 tahun, dan topik kedua tentang pengenalan dan evaluasi tumbuh kembang anak 0-2 tahun. Acara kegiatan diakhiri dengan sesi tanya jawab, post test, pembagian buku saku berjudul "Sehat \& Cerdas Berkat Gizi Seimbang".

Evaluasi peningkatan pengetahuan tentang gizi seimbang untuk anak usia 0-2 tahun

dilakukan dengan membandingkan nilai pre dan post test. Hasilnya dapat dilihat pada tabel dibawah ini:

Tabel 1. Evaluasi Peningkatan Pengetahuan Peserta

\begin{tabular}{|c|c|c|c|}
\hline No & $\begin{array}{c}\text { Pertanyaan } \\
\text { (tingkat } \\
\text { pengetahuan } \\
\text { peserta) }\end{array}$ & $\begin{array}{c}\text { Pre test } \\
\text { \% } \\
\text { (jawaban } \\
\text { benar) }\end{array}$ & $\begin{array}{c}\text { Post test } \\
\text { (jawaban } \\
\text { benar) }\end{array}$ \\
\hline 1 & $\begin{array}{l}\text { Pengetahuan } \\
\text { tentang ASI }\end{array}$ & 85 & 95 \\
\hline 3. & $\begin{array}{l}\text { Pengetahuan } \\
\text { tentang MPASI }\end{array}$ & 59 & 79 \\
peran & $\begin{array}{l}\text { kecukupan gizi } \\
\text { pada tumbuh } \\
\text { kembang anak }\end{array}$ & 84 \\
\hline
\end{tabular}


Sri dkk. Edukasi Gizi Seimbang Anak Usia 0-2 Tahun Pada Ibu-Ibu Di Kelurahan Harapan Mulia, Kemayoran/ Jakarta Pusat

Berdasarkan hasil pre-test, tingkat pengetahuan peserta tentang pengertian dan pentingnya asupan gizi seimbang dalam periode 0-2 tahun masih sangat terbatas (khususnya berkaitan dengan MPASI, karena hanya $59 \%$ peserta dapat menjawab benar pertanyaan terkait MPASI), sedangkan pengetahuan tentang ASI cukup baik (85\%). Didapatkan peningkatan pengetahuan peserta pada akhir kegiatan, tentang ASI dari $85 \%$ menjadi $95 \%$, sedangkan untuk MPASi dari 59\% menjadi $79 \%$.

Kebutuhan gizi sangat bervariasi sesuai tahapan umur. Di dalam kandungan, janin akan tumbuh dan berkembang melalui pertambahan badan dan panjang badan, perkembangan otak serta organ-organ lainnya. Pada saat dilahirkan, sebagian besar perubahan tersebut menetap atau selesai, kecuali beberapa fungsi, yaitu perkembangan otak dan imunitas, yang berlanjut sampai beberapa tahun pertama kehidupan. Oleh karena itu kekurangan nutrisi sejak dalam kandungan dan periode awal kehidupan akan berdampak pada tumbuh kembang dalam jangka waktu panjang antara lain anak yang stunting, kemampuan kognitif yang lemah serta berisiko terkena penyakit tidak menular, seperti anemia, hipertensi, diabetes dan lainlain.

Tumbuh kembang merupakan ciri khas anak dan salah satu indikator kesehatan anak. Pertumbuhan (growth) adalah pertambahan kuantitas massa tubuh, yang biasanya diukur melalui penimbangan berat badan (dalam satuan kilogram) dan pengukuran tinggi badan (dalam satuan meter). Selain menggambarkan pertumbuhan, ukuran tubuh dapat digunakan untuk menentukan status gizi dan komposisi tubuh. Dalam kegiatan PkM ini, pengetahuan peserta tentang dampak kekurangan gizi pada tumbuh kembang anak tampak cukup baik. dan diakhir kegiatan didapatkan peningkatan pengetahuan, yaitu dari $70 \%$ menjadi $84 \%$.

\section{FOTO KEGIATAN}

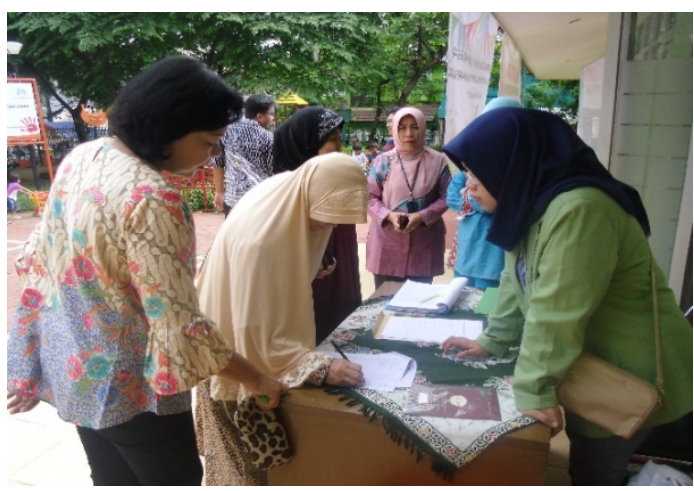

Gambar 1. Pendaftaran Peserta dibantu oleh mahasiswa Fakultas Kedokteran

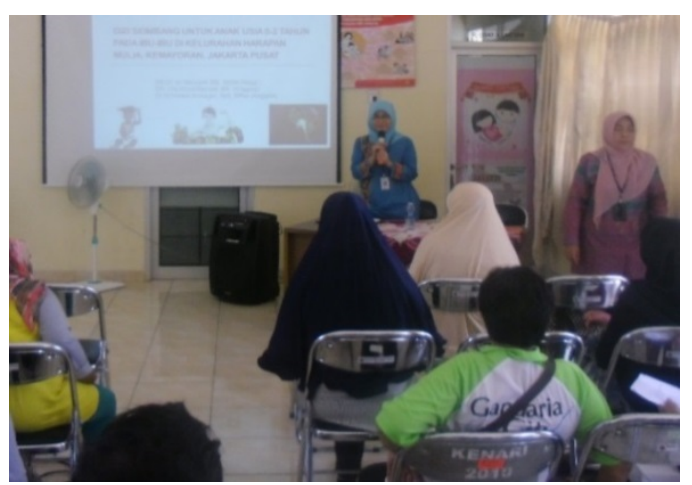

Gambar 2. Pemberian Materi Penyuluhan

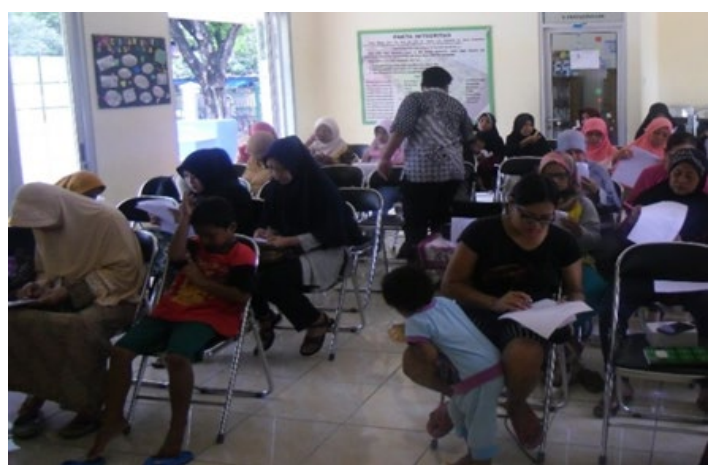

Gambar 3. Peserta mengisi Kuisioner 


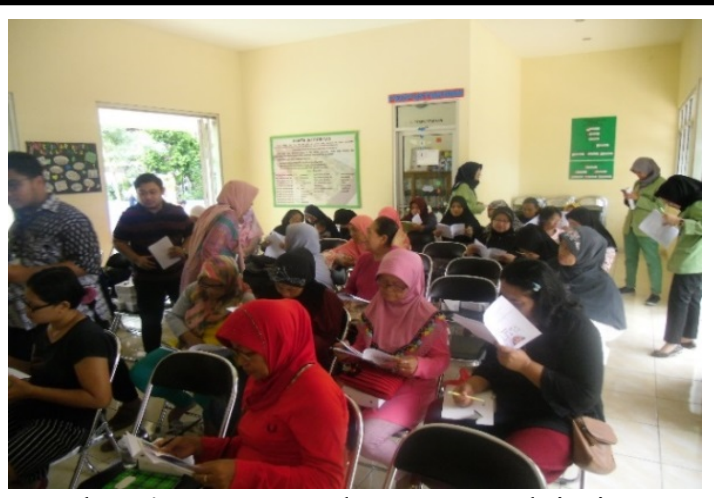

Gambar 4. Peserta sedang mempelajari buku saku "Sehat \& Cerdas Berkat Gizi Seimbang"

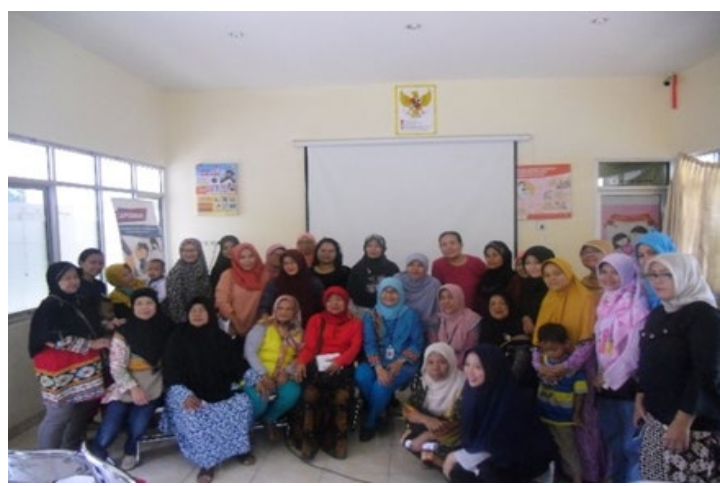

Gambar 5. Foto bersama peserta

\section{KESIMPULAN}

Telah dilakukan penyuluhan tentang gizi seimbang untuk anak usia $0-2$ tahun pada Ibu-ibu kader, WUS, ibu hamil dan ibu yang mempunyai anak baduta atau balita di kelurahan Harapan Mulia, Kecamatan Kemayoran, Jakarta-Pusat. Dari kegiatan ini didapatkan peningkatan pengetahuan peserta tentang ASI, MPASI, serta peran kecukupan gizi pada tumbuh kembang anak.

\section{SARAN}

Perlu dilakukan pembinaan/penyegaran secara berkala dan berkelanjutan agar materi yang disampaikan dalam penyuluhan dapat disebar luaskan dan diaplikasikan dalam mengatur menu keluarga khususnya untuk baduta/balita, serta melakukan monitor dan evaluasi status gizi dan tumbuh kembang anak melalui kegiatan Posyandu.

\section{UCAPAN TERIMA KASIH}

Ucapan terima kasih kami sampaikan kepada Yayasan Universitas YARSI, Wakil Rektor III yang membawahi kegiatan pengabdian masyarakat ini, Dekan Fakultas Kedokteran Universitas Yarsi, Dinas Kesehatan Jakarta Pusat, mitra kami yaitu Bina Keluarga Balita Kelurahan Harapan Mulia/Kecamatan Kemayoran, Jakarta Pusat yang telah membantu kami dalam menyelesaikan pengabdian masyarakat ini.

\section{DAFTAS PUSTAKA}

Endang L. Achadi, Kusharisupeni, Atmarita, Rahmi Untoro. Status Gizi Ibu Hamil dan Penyakit Tidak menular pada dewasa. Jurnal Kesehatan Masyarakat Nasional Vol.7, No. 4, November, 2012

Kemenkes RI, 2010. Deteksi dan Intervensi Dini Tumbuh Kembang. Kemenkes : Jakarta

Kerangka Kebijakan Gerakan Nasional Percepatan Perbaikan Gizi dalam Rangka Seribu Hari Pertama Kehidupan (Gerakan 1000 HPK), Republik Indonesia 2013

Murti, B., 2011. Kesehatan Anak dan Epidemiologi Sepanjang Hayat. Editorial Jurnal Kedokteran Indonesia, Vol.2, No.1 Januari 2011.

Summary Lancet Breatsfeeding Series in Indonesia; Implementasi Pelayanan Kesehatan Masyarakat; Penayangan video kampanye Gizi Tinggi Prestasi, UNICEF, 2016.

Mcwhinney I dan Freeman T, 2009, Texbook of Family Medicine 3rd ed. Oxford University Press Inc : Newyork

Proceeding of The Pediatric Nutrition and Metabolic Update Nutrimet "Best Practice in Nutrition \& Metabolic Disease in the First 1000 Days of Life, April 30-May 1, 2017 